\section{Still a way to go for South Africa's science revolution}

In the two decades that have passed since Nelson Mandela's release from prison, everything in South Africa has been revolutionized, including science. The country has hosted big science projects. Research and development expenditure has risen from $0.4 \%$ of gross domestic product in 1994 to just under $1 \%$ in 2008. However, this percentage is still too low.

Progress is being impeded by the country's small science base. It is also being impeded by an unjust patent regime. This rewards holders of dubious patents while deterring development of beneficial competitive products and services.

South Africa's Companies and Intellectual Property Registration Office awards patents without investigating the novelty of the invention. Only the documentation needs to be verified - not the substance of the product or process. If the patent application is challenged after it has been awarded, the applicant is responsible for ensuring that it is valid, and can incur substantial legal fees. Meanwhile, competitors have to monitor all new patents.

Nevertheless, South Africa ranks twelfth in the world for the strength of its patent-protection regime, on a par with France, Israel, Singapore and Switzerland (W. G. Park Res. Policy 37, 761-766; 2008). This situation arose in part because of the modus operandi and a limited expertise on intellectualproperty rights. There is also the threat of sanctions by the US government, which takes action to protect US companies' patents.

South Africa's Technology Innovation Agency was established in 2008 to bridge the country's 'innovation chasm' - a gap between locally produced knowledge and the products and services developed from it. But the fault lies not in a gap, but in a paucity of locally produced

knowledge. The science base is too small: for example, the percentage of South Africa's pupils enrolling in higher education is a quarter that of the United States and western Europe.

These concerns are being addressed by the government departments of trade, of industry and of higher education - but none of these has science and technology as its main responsibility. We hope that the newly formed National Planning Commission will be more effective with respect to innovation policy.

Anastassios Pouris Institute for

Technological Innovation, University of Pretoria,

Pretoria 0002, South Africa

e-mail: anastassios.pouris@up.ac.za

\section{Iranian physics society striving to prevent misconduct}

Allegations of unethical behaviour by a few Iranian scientists have recently been highlighted in the media, and notably in Nature (Nature 461, 578-579; 462, 699, 704-705; 2009). Although the Physics Society of Iran (PSI), of which I am president, believes that such misconduct is rare among the Iranian physics community, we intend to prevent it by every means available.

The PSI has been sensitive to this issue since 2004, when its ethics committee was established and an internal report was submitted to the board of directors. The PSI committee is at present investigating the factors behind this multifaceted phenomenon.

Our attempts to control digressions within our community include publicizing a code of ethical conduct, increasing awareness by wider education and raising the issues at conferences. A panel discussion is planned for our annual national meeting this summer.
Since the committee report, a code of ethics has been posted on its website (see go.nature.com/ EYYDjR, in Farsi) for discussion among PSI members. The final document is to be released soon after the annual meeting.

We have learned that similar efforts are already under way in several Iranian universities and institutes, including Sharif University of Technology and the Institute for Research in Fundamental Sciences, both in Tehran.

Hadi Akbarzadeh Department of Physics, Isfahan University of Technology, Isfahan 84156-83111, Iran e-mail: akbarzad@cc.iut.ac.ir

\section{Italy's stem-cell challenge gaining momentum}

Last summer we unsuccessfully challenged the Italian government in the courts, over its decision to exclude human embryonic stem cells from a ministerial researchfunding call for projects studying the biology and therapeutic use of stem cells (see Nature 460, 19 , 449; 2009). As scientists concerned about inappropriate political interference in scientific affairs, we intend to continue the fight through the courts, even if it takes years.

The case is politically and culturally significant, particularly in Italy. We believe this exclusion of a research topic that is legal and scientifically important amounts to an abuse of power.

Widespread indifference makes this battle difficult. We hope to alert the entire scientific community inside and outside Italy to the importance of an open discussion on how public money for research is allocated, and to warn students, the media, politicians and academics about the risk of any type of ideological conditioning of science.

It is bad enough for our chronically cash-starved community that the Italian government is cutting funding for research, innovation and education in the face of the current financial crisis, and that the government's system for funding distribution is less transparent than it should be.

Italian scientists doing basic research must fight back if they do not want to be marginalized from the international scene.

Elena Cattaneo Università degli Studi di Milano, Milan 20122, Italy e-mail: elena.cattaneo@unimi.it Elisabetta Cerbai Università degli Studi di Firenze, Florence 50121, Italy Silvia Garagna Università degli Studi di Pavia, Pavia 27100, Italy

\section{Did the bunny sell or sully the story on toxicity testing?}

I question your use of the photograph of a rabbit to illustrate a News story about the European Chemicals Agency (Nature 463, 142-143; 2010).

Rats, not rabbits, are mainly used in the reproductive-toxicity tests currently required over two generations of animals.

Safety assessments by REACH (Registration, Evaluation, Authorisation and Restriction of Chemicals) that are limited to a single generation could save millions of animals, making this an emotive issue. That could have been indirectly compounded by your caption, which alludes to the movie Watership Down, particularly as rabbits are seen as more endearing than rats. For the same reason, they may be more persuasive in selling the story. But it is irresponsible for a scientific journal to make the discussion on animal testing even more emotional than it already is.

Jan Backmann REACH, F. HoffmannLa Roche Ltd, Corporate Safety, Health and Environmental Protection, 4070 Basel, Switzerland e-mail:jan.backmann@roche.com

Contributions may be submitted tocorrespondence@nature. com. See the Guide to Authors at go.nature.com/cMCHno. 